\begin{tabular}{ll}
\hline \hline MINING AND METALLURGY INSTITUTE BOR & ISSN: 2334-8836 \\
& UDK: 622 \\
\hline \hline
\end{tabular}

Srđan Kostić, Dejan Vasović, ${ }^{* *}$, Ruža Okrajnov Bajic ${ }^{*}$

\title{
NEW FRESH CONCRETE CHEMICAL ADMIXTURE FOR TUNNEL LINING DESIGN IN THE EXTREME WINTER CONDITIONS ${ }^{* * *}$
}

\begin{abstract}
A new type of calcium-nitrate and urea-based chemical admixture is proposed, in order to maintain the compressive strength of fresh concrete exposed to very low temperatures (below to $25^{\circ} \mathrm{C}$ ), including a sudden transition to positive temperatures at an early age. The applied admixture has no negative effect on compressive strength of specimens cured in water at $20^{\circ} \mathrm{C}$. When it is cured under three different frost regimes, concrete specimens with admixture show over three times higher compressive strength, in comparison to specimens without admixture. The implications of such improved concrete composition are discussed in reference to the tunnel lining design.

Keywords: frost protection, compressive strength, anti-freezing admixture, tunnel lining
\end{abstract}

\section{INTRODUCTION}

Tunnel advance in weak rock masses requires an appropriate lining design, in order to prevent high inward displacements of rock masses, tunnel roof collapse or jamming/damage of tunnel boring machines, before the final support is installed. The process of supporting the rock mass usually initiates with adequate distribution of rock bolts, modifying the properties of rock mass in much the same way as reinforcement does in concrete. In the same time, since the final support is typically installed after some time elapsed from the excavation, and at some distance from the excavation point (using the "longitudinal arch" effect), a thin layer of shotcrete (sprayed concrete) is usually installed with the main task to reduce displacement and number of yielded bolt elements (regarding the elastic-perfectly plastic behavior of rock mass) [1]. Properties of such shotcrete are determined according to specific tunnel design and geological conditions. However, an important issue that has to be considered is the time - dependent properties of the shotcrete layer. For example, if the tunnel lining, consisting of rock bolts and shotcrete with steel lattice girders, is installed right behind the tunnel face and

\footnotetext{
* Department of Geology, University of Belgrade Faculty of Mining and Geology, Djušina 7, 11000 Belgrade, srdjan.kostic@rgf.bg.ac.rs

** Department of Architectural Technologies, University of Belgrade Faculty of Architecture, Belgrade, Serbia

*** This research was partly supported by the Ministry of Education, Science and Technological Development of the Republic of Serbia (Project No. 176016).
} 
activated immediately, the rock-bolts and lattice girders respond to the deformation of the rock mass surrounding the tunnel as soon as the tunnel advances. However, the shotcrete is only one day old at this stage, and it has not yet developed its full capacity, so the current load may be sufficient to induce failure in the shotcrete. Considering this, it is important to assure that shotcrete reaches the expected short-term value of compressive strength by protecting it from the unfavorable outdoor conditions, e.g. sudden freezing and thawing cycles. It should be noted that for tunnel advance in frost conditions, it is not necessary to use the shotcrete mixture which provides freeze/thaw resistant hardened concrete, but to have a fresh concrete mixture resistant to possible freezing [2-3]. According to [4], concrete has to be protected against freezing until the degree of saturation is significantly reduced due to hydration process, corresponding to the time when concrete reaches a compressive strength of $3.5 \mathrm{MPa}$ [5], which is typically achieved in the first $24 \mathrm{~h}$ for concrete mixtures with $\mathrm{W} / \mathrm{C}$ ratio below 0.6 and exposed to $\mathrm{t}=20^{\circ} \mathrm{C}$. If concrete is exposed to freezing before this time, its compressive strength will be sig-nificantly reduced [6]. Considering this, it is of special interest to investigate the frost resistance of fresh concrete in winter months, when minimum recorded daily temperatures may reach even below $-10^{\circ} \mathrm{C}$ with up to 15 days with the average daily temperature below zero [7]. In such cases, water freezing in fresh concrete could permanently damage the structure of newly formed cement matrix.

Even though, there are many previous studies on the impact of low temperatures on compressive strength of concrete [8$11]$, none of them investigate the influence of severe frost on fresh concrete, with tem peratures down to $-25^{\circ} \mathrm{C}$, including the effect of quick temperature changes, with amplitude up to $45^{\circ} \mathrm{C}$ in just several days. The main motivation for performing such research lies in the justified need for an antifreeze admixture, considering the real temperature regimes recorded in Belgrade, with frequent cases of severe frost. Such extreme frost conditions could have happened during the TBM excavation of hydrotechnical tunnel in Višnjica near Belgrade, leading to the possible machine jamming.

The aim of research is to develop a reliable admixture, which could enable tunnel lining without frost protection even in such severe climate conditions. Considering this, the impact of different amount of proposed chemical admixture $(4 \%$ and $8 \%$ ) is investigated on compressive strength of fresh concrete under three different frost regimes: one-day frost $\left(-10^{\circ} \mathrm{C}\right)$, threeday frost $\left(-10^{\circ} \mathrm{C},-5^{\circ} \mathrm{C}\right.$ and $\left.-15^{\circ} \mathrm{C}\right)$, and seven-day frost (oscillating from $0^{\circ} \mathrm{C}$ up to $\left.-25^{\circ} \mathrm{C}\right)$.

\section{DURATION OF FROST IN REAL CONDITIONS}

In order to motivate a need for field application of such an anti-freeze admixture, a review on the climatic properties in Belgrade for period 1993-2012 is given according to the observations made by the Republic Hydrometeorological Service of Serbia [7]. In order to justify the testing of concrete under the first and second frost regime, the extreme examples of sudden warming for December, January, February and March in the period 1993-2012 were analyzed. Maximum temperature amplitudes (up to $16.8^{\circ} \mathrm{C}$ in February 1996) are shown in Figure 1 only for those days with sudden transition from negative to positive temperatures in two consecutive days. 
(a) 20

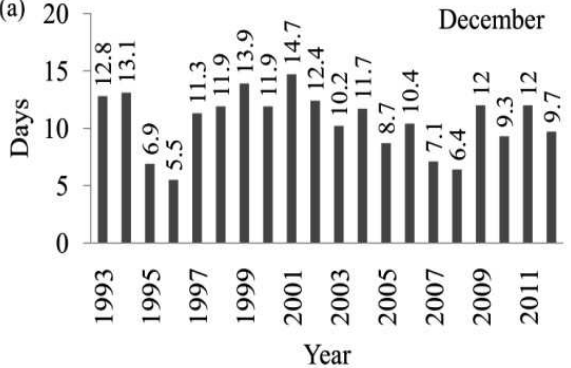

(c)

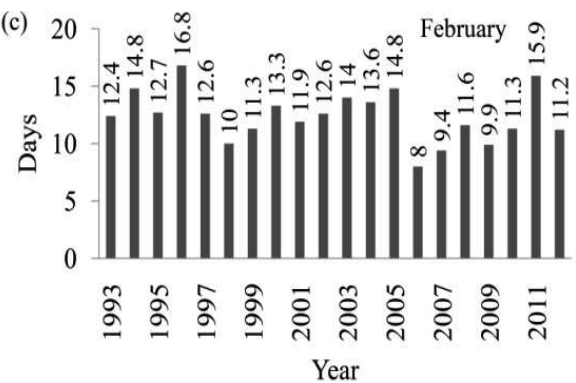

(b) $207 r \sqrt{0}$
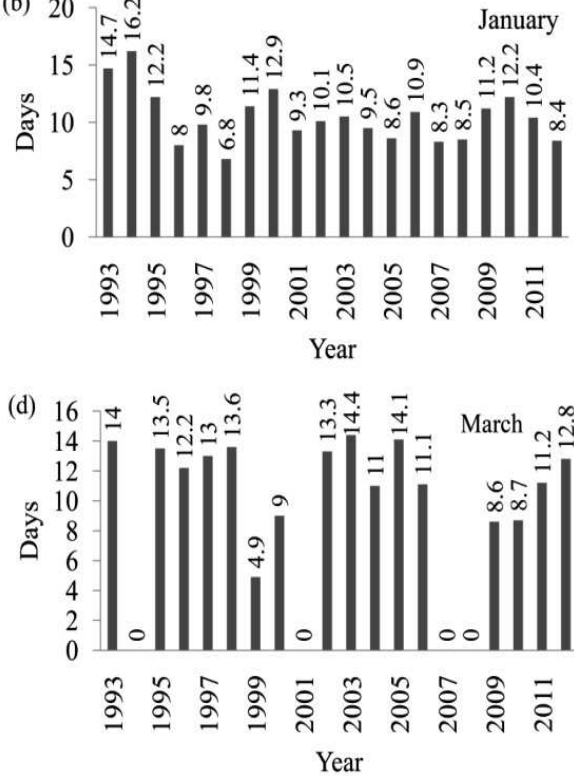

Figure 1 Maximum daily temperature amplitude with sudden transition from negative to the positive values for two consecutive days in the period 1993-2012 for the following months:

(a) December, (b) January, (c) February; (d) March. Zero value is assigned for months without a transition from negative to positive temperature

On the other hand, maximum number of consecutive days with frost is shown in Figure 2 (14 days in January 2009 and February 2012), which legitimizes the testing of concrete in the third frost regime, with sevenday continuous frost.

\section{EXPERIMENTAL PART}

In the first phase of research, the concrete compressive strength was determined with and without admixture after curing in water at the room temperature $\left(20^{\circ} \mathrm{C}\right)$. The second stage of the study comprises the analysis of admixture effect ( $4 \%$ and $8 \%$ ) on compressive strength of concrete specimens and after that they were exposed to three different frost regimes. The main constitutive elements of concrete were (Table 1): cement (CEM I 42.5 R, Lafarge Cement Factory Beočin, Serbia), andesite aggregate (crushed, quarry Šumnik, Serbia) and admixture ("T-25 $\left.{ }^{\circ} \mathrm{C} "\right)$. Cubic concrete specimens $(10 \times 10 \mathrm{~cm})$ were formed in a laboratory counter-current concrete mixer, with the mixing period of 3 minutes for all mixtures. Casting was performed at a vibrating table until a complete consolidation was achieved. 

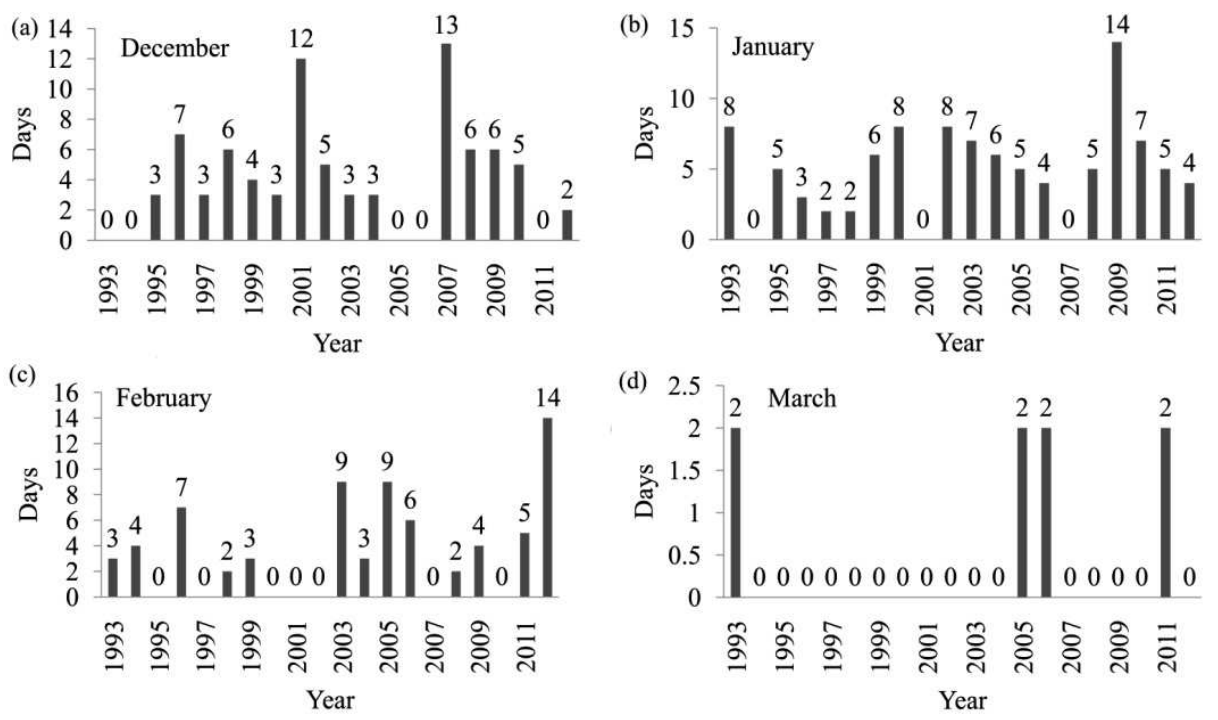

Figure 2 Number of consecutive days with the temperature below 00C in the period 1993-2012 for the following months: (a) December, (b) January, (c) February;

(d) March (only two or more days are taken into account)

Table 1 Proportions of concrete mixtures

\begin{tabular}{|l|c|c|c|}
\hline \multicolumn{1}{|c|}{ constituent per $1 \mathrm{~m}^{3}$ of concrete } & admixture 0\% & admixture $4 \%$ & admixture 8\% \\
\hline cement: CEM I 42,5 R & $417 \mathrm{~kg}$ & $411 \mathrm{~kg}$ & $408 \mathrm{~kg}$ \\
\hline andesite aggregate $0-2 \mathrm{~mm}(30 \%)$ & $574 \mathrm{~kg}$ & $567 \mathrm{~kg}$ & $563 \mathrm{~kg}$ \\
\hline andesite aggregate $2-4 \mathrm{~mm}(10 \%)$ & $192 \mathrm{~kg}$ & $189 \mathrm{~kg}$ & $188 \mathrm{~kg}$ \\
\hline andesite aggregate $4-8 \mathrm{~mm}(10 \%)$ & $192 \mathrm{~kg}$ & $189 \mathrm{~kg}$ & $188 \mathrm{~kg}$ \\
\hline andesite aggregate $8-11 \mathrm{~mm}(20 \%)$ & $383 \mathrm{~kg}$ & $378 \mathrm{~kg}$ & $375 \mathrm{~kg}$ \\
\hline andesite aggregate $11-16 \mathrm{~mm} \mathrm{(30 \% )}$ & $575 \mathrm{~kg}$ & $568 \mathrm{~kg}$ & $563 \mathrm{~kg}$ \\
\hline admixture & - & $16,4 \mathrm{~kg}$ & $32,6 \mathrm{~kg}$ \\
\hline water & $167 \mathrm{~kg}$ & $148 \mathrm{~kg}$ & $139 \mathrm{~kg}$ \\
\hline W/C ratio & 0.40 & 0.36 & 0.34 \\
\hline unit weight & $2500 \mathrm{~kg} / \mathrm{m}^{3}$ & $2467 \mathrm{~kg} / \mathrm{m}^{3}$ & $2456 \mathrm{~kg} / \mathrm{m}^{3}$ \\
\hline
\end{tabular}

Concrete specimens for the first set of tests (isothermal curing conditions) were prepared as described above and cast in steel moulds. After 24 hours, the reference samples were taken out of the moulds and cured under the same conditions in water at $20^{\circ} \mathrm{C}$. The compressive strength was determined after 3,7 and 28 days. In the second phase of the experimental part of the research, test specimens were made in the same way as in the previous test $(10 \times 10 \mathrm{~cm}$ cubes). The temperature of mixtures during casting was $20^{\circ} \mathrm{C}$. Immediately upon casting, metal moulds with fresh concrete were put in the acclimatization chamber at $-10^{\circ} \mathrm{C}$, and exposed to three different frost regimes: (a) 


\section{EXPERIMENTAL RESULTS}

frost regime 1 simulates temporary one-day frost, with specimens exposed to $-10^{\circ} \mathrm{C}$ on the first day and cured in water at $20^{\circ} \mathrm{C}$ during the following day; (b) frost regime 2 simulates several-day frost, with first-day exposure to $-10^{\circ} \mathrm{C}$, second-day exposure to $5^{\circ} \mathrm{C}$, third-day exposure to $-15^{\circ} \mathrm{C}$ and, during the fourth day, the specimens were cured in water at $20^{\circ} \mathrm{C}$; (c) frost regime 3 simulates a long, seven-day period of frost, with first-day exposure to $-10^{\circ} \mathrm{C}$, secondday exposure to $-5^{\circ} \mathrm{C}$, third-day exposure to $-15^{\circ} \mathrm{C}$, fourth-day exposure to $-25^{\circ} \mathrm{C}$, fifthday exposure to $-10^{\circ} \mathrm{C}$ and sixth-day and seventh-day exposure to $-5^{\circ} \mathrm{C}$. From the eighth to twenty-eighth day, test specimens were cured in water at $20^{\circ} \mathrm{C}$.
Results of the first phase of research are shown in Table 2. It is clear that concrete compressive strength with admixture after 3 days is larger when compared to the specimens without admixture. However, after 7 days, a slightly larger compressive strength is observed for the concrete with $4 \%$ of admixture, while significantly lower strength is determined for the concrete with $8 \%$ of admixture. On the other side, after 28 days compressive strength increases for the concrete with $4 \%$ of admixture and then slightly drops for samples with $8 \%$ of admixture, but it is still higher when compared to the specimens without admixture. The testing proved that the addition of admixture had no negative effect on the concrete hardening after 28 days.

Table 2 Properties of concrete samples with different \% of admixture cured in water at $20^{\circ} \mathrm{C}^{*}$

\begin{tabular}{|c|c|c|c|c|c|c|c|}
\hline \multirow{2}{*}{ Sp. No. } & \multirow{2}{*}{ Age (days) } & \multicolumn{2}{|c|}{$0 \%$ admixture } & \multicolumn{2}{|c|}{$4 \%$ admixture } & \multicolumn{2}{|c|}{$8 \%$ admixture } \\
\hline & & $\begin{array}{c}\gamma \\
\left(\mathrm{kg} / \mathrm{m}^{3}\right)\end{array}$ & $\begin{array}{c}\sigma_{\mathrm{c}} \\
(\mathrm{MPa})\end{array}$ & $\begin{array}{c}\gamma \\
\left(\mathrm{kg} / \mathrm{m}^{3}\right)\end{array}$ & $\begin{array}{c}\sigma_{\mathrm{c}} \\
(\mathrm{MPa})\end{array}$ & $\begin{array}{c}\gamma \\
\left(\mathrm{kg} / \mathrm{m}^{3}\right)\end{array}$ & $\begin{array}{c}\sigma_{\mathrm{c}} \\
(\mathrm{MPa})\end{array}$ \\
\hline 1 & \multirow{3}{*}{3} & 2470 & 52.0 & 2405 & 57.5 & 2490 & 61.0 \\
\hline 2 & & 2460 & 52.0 & 2420 & 58.0 & 2480 & 62.0 \\
\hline 3 & & 2460 & 51.0 & 2490 & 54.5 & 2480 & 65.0 \\
\hline 4 & \multirow{3}{*}{7} & 2470 & 77.4 & 2470 & 74.5 & 2420 & 66.2 \\
\hline 5 & & 2580 & 73.8 & 2450 & 78.0 & 2460 & 64.0 \\
\hline 6 & & 2450 & 72.0 & 2450 & 72.0 & 2440 & 68.5 \\
\hline 7 & \multirow{3}{*}{28} & 2460 & 88.5 & 2450 & 93.0 & 2470 & 83.7 \\
\hline 8 & & 2470 & 70.6 & 2470 & 84.0 & 2470 & 96.5 \\
\hline 9 & & 2440 & 81.0 & 2450 & 90.0 & 2430 & 81.6 \\
\hline
\end{tabular}

${ }^{*}$ Sp. No. denotes specimen number, $\gamma$ represents unit weight and $\sigma_{c}$ denotes compressive strength of concrete.

In the second stage of analysis, concrete compressive strength was determined under the various frost regimes up to $-25^{\circ} \mathrm{C}$.
Firstly, the effects of water freezing in fresh concrete without chemical admixtures are tested (Table 3). 
Table 3 Properties of concrete samples without admixture

\begin{tabular}{|c|c|c|c|c|c|c|c|c|}
\hline \multirow{2}{*}{$\begin{array}{l}\text { Sp. } \\
\text { No. }\end{array}$} & \multirow{2}{*}{$\begin{array}{l}\text { frost } \\
\text { regime }\end{array}$} & \multicolumn{2}{|c|}{ age (days) } & \multirow{2}{*}{ equivalent age $\left(\mathrm{t}_{\mathrm{e}}\right)^{*}$} & \multicolumn{4}{|c|}{ concrete without admixture } \\
\hline & & $<0^{\circ} \mathrm{C}$ & $=20^{\circ} \mathrm{C}$ & & $\gamma\left(\mathrm{kg} / \mathrm{m}^{3}\right)$ & average & $\sigma_{\mathrm{c}}(\mathrm{MPa})$ & average \\
\hline 1 & 1 & 1 & 1 & 1 & 2455 & \multirow{2}{*}{2478} & 7.9 & \multirow{2}{*}{8.2} \\
\hline 2 & 1 & 1 & 1 & 1 & 2500 & & 8.5 & \\
\hline 3 & 2 & 3 & 1 & 1 & 2430 & \multirow{2}{*}{2420} & 10.1 & \multirow{2}{*}{10.2} \\
\hline 4 & 2 & 3 & 1 & 1 & 2410 & & 10.4 & \\
\hline 5 & 3 & 7 & 1 & 0.83 & 2410 & \multirow{3}{*}{2400} & 11.8 & \multirow{3}{*}{12.1} \\
\hline 6 & 3 & 7 & 1 & 0.83 & 2390 & & 12.4 & \\
\hline 7 & 3 & 7 & 1 & 0.83 & 2355 & & 16.7 & \\
\hline 8 & 3 & 7 & 3 & 2.83 & 2530 & \multirow{3}{*}{2425} & 19.0 & \multirow{3}{*}{17.6} \\
\hline 9 & 3 & 7 & 3 & 2.83 & 2390 & & 17.1 & \\
\hline 10 & 3 & 7 & 3 & 2.83 & 2390 & & 21.0 & \\
\hline 11 & 3 & 7 & 7 & 6.83 & 2410 & \multirow{3}{*}{2397} & 21.8 & \multirow{3}{*}{21.5} \\
\hline 12 & 3 & 7 & 7 & 6.83 & 2390 & & 21.8 & \\
\hline 13 & 3 & 7 & 7 & 6.83 & 2525 & & 31.0 & \\
\hline 14 & 3 & 7 & 28 & 27.83 & 2410 & \multirow{2}{*}{2440} & 28.0 & \multirow{2}{*}{29.3} \\
\hline 15 & 3 & 7 & 28 & 27.83 & 2385 & & 29.0 & \\
\hline
\end{tabular}

* equivalent age $\left(t_{e}\right)$ is determined according to the Saul model [12]

The results of experimental research on concrete specimens with $4 \%$ and $8 \%$ of admixture are shown in Tables 4 and 5 . In both cases, compressive strength of concrete specimens is much higher, even over three times (for frost regime 1 from $8.2 \mathrm{MPa}$ to $25.9 \mathrm{MPa}$ with $4 \%$ of admixture), when compared to the concrete strength without the admixture (Table 3 ).

Table 4 Properties of concrete samples with 4\% admixture

\begin{tabular}{|c|c|c|c|c|c|c|c|c|}
\hline \multirow[b]{2}{*}{$\begin{array}{l}\text { Sp. } \\
\text { No. }\end{array}$} & \multirow[b]{2}{*}{$\begin{array}{l}\text { frost } \\
\text { regime }\end{array}$} & \multicolumn{2}{|c|}{ age (days) } & \multirow[b]{2}{*}{ equivalent age $\left(\mathrm{t}_{\mathrm{e}}\right)$} & \multicolumn{4}{|c|}{ concrete with $4 \%$ admixture } \\
\hline & & $<0^{\circ} \mathrm{C}$ & $=20^{\circ} \mathrm{C}$ & & $\begin{array}{c}\gamma \\
\left(\mathrm{kg} / \mathrm{m}^{3}\right)\end{array}$ & average & $\sigma_{\mathrm{c}}(\mathrm{MPa})$ & average \\
\hline 1 & 1 & 1 & 1 & 1 & 2440 & \multirow{2}{*}{2445} & 25.8 & \multirow{2}{*}{25.9} \\
\hline 2 & 1 & 1 & 1 & 1 & 2450 & & 26.0 & \\
\hline 3 & 2 & 3 & 1 & 1 & 2470 & \multirow{2}{*}{2460} & 15.2 & \multirow{2}{*}{15.6} \\
\hline 4 & 2 & 3 & 1 & 1 & 2450 & & 16.1 & \\
\hline 5 & 3 & 7 & 1 & 0.83 & 2440 & \multirow{3}{*}{2445} & 26.0 & \multirow{3}{*}{25.2} \\
\hline 6 & 3 & 7 & 1 & 0.83 & 2450 & & 24.3 & \\
\hline 7 & 3 & 7 & 1 & 0.83 & 2380 & & 31.0 & \\
\hline 8 & 3 & 7 & 3 & 2.83 & 2380 & \multirow{3}{*}{2390} & 31.5 & \multirow{3}{*}{31.5} \\
\hline 9 & 3 & 7 & 3 & 2.83 & 2410 & & 32.0 & \\
\hline 10 & 3 & 7 & 3 & 2.83 & 2370 & & 45.0 & \\
\hline 11 & 3 & 7 & 7 & 6.83 & 2410 & \multirow{3}{*}{2390} & 39.5 & \multirow{3}{*}{43.1} \\
\hline 12 & 3 & 7 & 7 & 6.83 & 2390 & & 44.8 & \\
\hline 13 & 3 & 7 & 7 & 6.83 & 2440 & & 50.7 & \\
\hline 14 & 3 & 7 & 28 & 27.83 & 2460 & \multirow{2}{*}{2453} & 53.8 & \multirow{2}{*}{53.6} \\
\hline 15 & 3 & 7 & 28 & 27.83 & 2460 & & 56.4 & \\
\hline
\end{tabular}


Table 5 Properties of concrete samples with 8\% admixture

\begin{tabular}{|c|c|c|c|c|c|c|c|c|}
\hline \multirow{2}{*}{$\begin{array}{l}\text { Sp. } \\
\text { No. }\end{array}$} & \multirow{2}{*}{$\begin{array}{l}\text { frost } \\
\text { regime }\end{array}$} & \multicolumn{2}{|c|}{ age (days) } & \multirow[b]{2}{*}{ equivalent age $\left(\mathrm{t}_{\mathrm{e}}\right)$} & \multicolumn{4}{|c|}{ concrete with $8 \%$ admixture } \\
\hline & & $<0^{\circ} \mathrm{C}$ & $=20^{\circ} \mathrm{C}$ & & $\gamma\left(\mathrm{kg} / \mathrm{m}^{3}\right)$ & average & $\sigma_{\mathrm{c}}(\mathrm{MPa})$ & average \\
\hline 1 & 1 & 1 & 1 & 1 & 2440 & \multirow{2}{*}{2440} & 17.0 & \multirow{2}{*}{17.6} \\
\hline 2 & 1 & 1 & 1 & 1 & 2440 & & 18.1 & \\
\hline 3 & 2 & 3 & 1 & 1 & 2430 & \multirow{2}{*}{2445} & 24.0 & \multirow{2}{*}{23.8} \\
\hline 4 & 2 & 3 & 1 & 1 & 2460 & & 23.7 & \\
\hline 5 & 3 & 7 & 1 & 0.83 & 2430 & \multirow{3}{*}{2435} & 38.7 & \multirow{3}{*}{39.4} \\
\hline 6 & 3 & 7 & 1 & 0.83 & 2440 & & 40.2 & \\
\hline 7 & 3 & 7 & 1 & 0.83 & 2410 & & 41.0 & \\
\hline 8 & 3 & 7 & 3 & 2.83 & 2385 & \multirow{3}{*}{2402} & 40.0 & \multirow{3}{*}{40.5} \\
\hline 9 & 3 & 7 & 3 & 2.83 & 2410 & & 40.5 & \\
\hline 10 & 3 & 7 & 3 & 2.83 & 2410 & & 46.3 & \\
\hline 11 & 3 & 7 & 7 & 6.83 & 2420 & \multirow{3}{*}{2403} & 46.5 & \multirow{3}{*}{47.9} \\
\hline 12 & 3 & 7 & 7 & 6.83 & 2380 & & 51.0 & \\
\hline 13 & 3 & 7 & 7 & 6.83 & 2430 & & 56.1 & \\
\hline 14 & 3 & 7 & 28 & 27.83 & 2450 & \multirow{2}{*}{2443} & 69.4 & \multirow{2}{*}{61.0} \\
\hline 15 & 7 & 7 & 28 & 27.83 & 2450 & & 57.4 & \\
\hline
\end{tabular}

It is necessary to emphasize that the difference in behaviour of concrete specimens with $4 \%$ and $8 \%$ admixture is rather small, indicating that further increase in admixture dosage would not significantly increase the concrete compressive strength. On the other hand, even though there is a significant increase of compressive strength when compared with the case without admixture (Tables 3, 4 and 5), the recorded values are still lower in comparison to the concrete specimens cured under isothermal conditions (Table 2). In order to compare the compressive strength of concrete samples under different frost regimes (with and without chemical additives) to the compressive strength of concrete specimens cured under isothermal conditions, the compressive strength of concrete is estimated after the following days: $0.83,1,2.83,6.83$ and 27.83 , which represent the equivalent age for all tested cases (fourth column in Tables 3, 4 and 5). The compressive strength at target days was estimated using the Plowman model (Figure 3), which expresses the relationship between compressive strength of concrete cured under isothermal conditions and maturity by the Saul:

$$
S_{p}=a+b \times \log M_{s},
$$

where

- $S_{p}$ - is the strength prediction value by the Plowman equation [13],

- $M_{s}$ - is the maturity by the Saul model [12] and

- $a$ and $b$ are constants.

Maturity of concrete $M_{s}$ was determined on the basis of equivalent age, which takes into account the combined effect of time and curing temperature on strength development [14]:

$$
t_{e}=\left(\sum_{1}^{n}\left(T-T_{0}\right) \times \Delta t_{i}\right) /\left(T_{r}-T_{0}\right),
$$

where

$-t_{e}$ - is the equivalent age,

- $T$ - is temperature at which concrete hardens in the time interval $\Delta t_{i}$,

- $T_{0}$ - indicates the reference temperature $\left(-10^{\circ} \mathrm{C}\right)$,

- $T_{r}$ - represents the concrete curing temperature $\left(20^{\circ} \mathrm{C}\right)$, and

- $\Delta t_{i}$ - represents the observed time interval.

It is obvious, based on Figure 3, that the Plowman model gives a reasonable estimation of experimental results, with 
high coeficient of correlation $(r>0.8)$ and small root mean squared error (RMSE $\leq$ 7.14). Thus the values of compressive

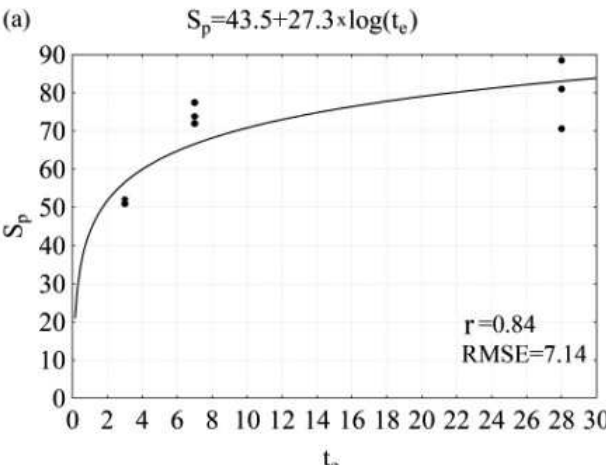

strength at target days could be read from these diagrams with reliable accuracy (fourth column in Tables 3, 4 and 5).

(b)

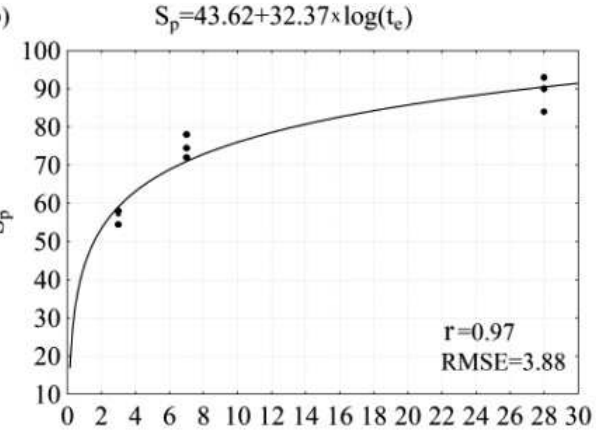

$t_{e}$

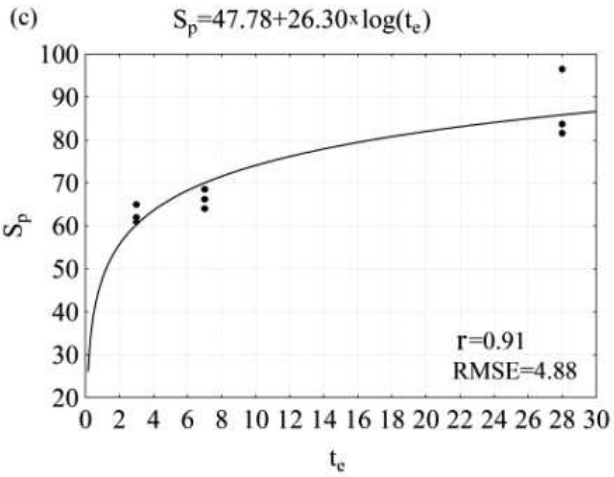

Figure 3 Regression results of the Plowman model for concrete specimens with different amount of admixture, cured under the isothermal conditions (in water at 200C): (a) $0 \%$ of admixture; (b) $4 \%$ of admixture; (c) $8 \%$ of admixture

Comparison of concrete compressive strength cured under isothermal conditions and after different frost regimes is shown in Table 6. It is clear that concrete specimens with $8 \%$ of admixture achieve $86.3 \%$ of the target compressive strength, for the third frost regime with seven days of frost and only one day of thawing. The same specimens achieve $71.1 \%$ of the target compressive strength for the third frost regime with seven days of frost and 21 days of thawing. In all other cases, the concrete specimens achieve less than $70 \%$ of the compressive strength of reference samples cured under isothermal conditions. 
Table 6 Decrease of compressive strength of concrete with and without admixture cured under the isothermal conditions and exposed to different temperature regimes

\begin{tabular}{|c|c|c|c|c|c|c|c|c|c|}
\hline \multirow[b]{2}{*}{ 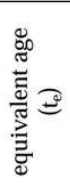 } & \multicolumn{3}{|c|}{$\sigma_{\mathrm{c}}(\mathrm{MPa})$ with $0 \%$ admixture } & \multicolumn{3}{|c|}{$\sigma_{\mathrm{c}}(\mathrm{MPa})$ with $4 \%$ admixture } & \multicolumn{3}{|c|}{$\sigma_{\mathrm{c}}(\mathrm{MPa})$ with $8 \%$ admixture } \\
\hline & 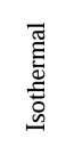 & 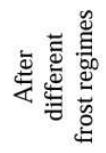 & 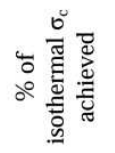 & 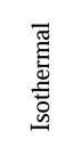 & 这总总 & 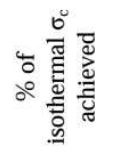 & 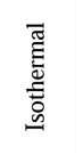 & 选离总总 & 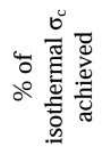 \\
\hline 0.83 & 41.29 & 12.1 & 29.3 & 41.00 & 25.2 & 61.5 & 45.65 & 39.4 & 86.3 \\
\hline 1 & 43.50 & $8.2-10.2$ & $18.9-23.5$ & 43.62 & $15.6-25.9$ & $35.8-59.4$ & 47.78 & $17.6-23.8$ & $36.8-49.8$ \\
\hline 2.83 & 55.83 & 17.6 & 31.5 & 58.24 & 31.5 & 54.1 & 59.66 & 40.5 & 67.9 \\
\hline 6.83 & 66.28 & 21.5 & 32.4 & 70.63 & 43.1 & 61.0 & 69.73 & 47.9 & 68.7 \\
\hline 27.83 & 82.94 & 29.3 & 35.3 & 90.38 & 53.6 & 59.3 & 85.77 & 61.0 & 71.1 \\
\hline
\end{tabular}

\section{CONCLUSION}

This work analyzes the effect of chemical admixture on compressive strength of concrete specimens under differrent frost regimes. In all three cases, concrete with admixture achieved considerably higher compressive strength (even 200\% higher for some regimes), when compared to the samples without admixture. The results of this analysis confirm that the use of chemical admixtures prevent breakage of fresh shotcrete tunnel lining even in such severe winter conditions.

It should be noted that comparison of recorded concrete compressive strength (Table 6) was carried out using the regression analysis, which could lead to ambiguous interpretations. However, relatively high value of correlation coefficient $(r>0.8)$ points out that possible error in estimated value lies in the range of a measurement error. On the other side, the present analysis was limited by the small number of concrete samples: for some regimes three concrete samples are tested, as it is common in laboratory testing, while in the other cases, properties of only two specimens were determined. However, even with large number of samples the significantly different results should not be expected from the standpoint of the achieved compressive strength.
Regarding the future research, further analysis of the proposed admixture effect should be carried out especially regarding the target of compressive strength. Certainly, this should be related to the economic benefits, aiming at low-cost percentage of admixture with maximum concrete compressive strength. These experiments would certainly be performed in situ, at excavated contour, which would also involve the impact of progressive inward displacement of rock masses on the development of shotcrete compressive strength. In that way, the effect of chemical admixture on the stability of fresh shotcrete tunnel lining would be evaluated more closely.

\section{REFERENCES}

[1] Hoek, E., Carranza-Torres, C., Diederichs, M., The 2008 Kersten Lecture: Integration of Geotechnical and Structural Design in Tunneling, Proceedings, $56^{\text {th }}$ Annual Geotechnical Engineering Conference, Minneapolis, 2008; pp. 53;

[2] Aitcin, P. C. The Durability Characteristics of High Performance Concrete: A Review. Cement Concrete Comp. 2003; 25: pp. 409-420; 
[3] Neville, A. M. Properties of Concrete. $5^{\text {th }}$ ed. Edinburgh: Pearson Education Limited; 2012;

[4] ACI 306 Committee, Guide to Cold Weather Concreting, ACI 306R-10, Farmington Hills, Michigan: American Concrete Institute; 2010;

[5] Powers, T. C. Prevention of Frost Damage to Green Concrete. RILEM 1962;14: 120-124;

[6] Kosmatka, S. H., Kerkhoff, B., Panarese, W. C. Design and Control of Concrete Mixtures. $14^{\text {th }}$ ed. Skokie, Illinois: Portland Cement Association; 2003;

[7] Yearbooks of Hydrometeorological Service of Serbia, 1993-2012;

[8] Nmai, C. K. Cold Weather Concreting Admixtures, Cement Concrete Comp. 1998; 20:121-128;

[9] Husem, M., Gozutok, S., The Effects of Low Temperature Curing on the Compressing Strength of Ordinary and High Performance Concrete, Constr. Build. Mater. 2005;19: 49-53;
[10] Barna, L. A., Seman, P. M., Korhonen, C. J., Energy-efficient Approach to Cold-weather Concreting, Journal of Materials in Civil Engineering, Special Issue: Energy Efficient and Environmentally Friendly Paving Materials 2011; 23: pp. 1544-1551;

[11] Cullu, M., Arslan, M., The effects of Antifreeze Use on Physical and Mechanical Properties of Concrete Produced in Cold Weather, Composites: Part B 2013; 50:pp. 202-209;

[12] Saul, A. G. A. Principles Underlying the Steam Curing of Concrete at Atmospheric Pressure, Mag. Concr. Res. 1951; 2: pp. 127-140;

[13] Plowman, J. M. Maturity and the Strength of Concrete. Mag. Concr. Res. 1956;8: pp. 13 - 22;

[14] Yi, S. T., Moon, Y. H., Kim, J. K., Long-term Strength Prediction of Concrete with Curing Temperature, Cement Concrete Res. 2005; 35; pp. 1961-1969. 


\begin{tabular}{ll}
\hline \hline INSTITUT ZA RUDARSTVO I METALURGIJU BOR & ISSN: 2334-8836 \\
& UDK: 622 \\
\hline \hline
\end{tabular}

Srđan Kostić, Dejan Vasovic ${ }^{* *}$, Ruža Okrajnov Bajić*

\section{NOVI HEMIJSKI DODATAK SVEŽEM BETONU \\ ZA IZVOĐENJE TUNELSKE OBLOGE U EKSTREMNIM ZIMSKIM USLOVIMA***}

Izvod

U radu se predlaže novi tip hemijskog dodatka betonu na bazi kalcijum-nitrata i uree, sa ciljem održavanja čvrstoće na pritisak svežeg betona izloženog vrlo niskim temperaturama $\left(\right.$ do $\left.-25^{0} \mathrm{C}\right)$, uključujući i uticaj iznenadnih velikih temperaturnih amplituda (prelaze od negativnih ka pozitivnim temperaturama). Primenjeni dodatak ne utiče nepovoljno na čvrstoću na pritisak uzoraka betona negovanih u izotermalnim uslovima na temperaturi od $20^{\circ} \mathrm{C}$. Kada se svež beton izloži uticaju različitih režima mraza, uzorci sa dodatkom pokazuju gotovo tri puta veću pritisnu čvrstoću u poređenju sa uzorcima bez dodatka. Primena betona sa predloženim aditivom u praksi razmatra se u odnosu na postojanost i stabilnost tunelske obloge sa prskanim betonom.

Ključne reči: zaštita od mraza, čvrstoća na pritisak, dodatak protiv zamrzavanja, obloga tunela

\section{UVOD}

Izvođenje tunela u „slabim” stenskim masama zahteva pravilno projektovanje tunelske obloge, radi sprečavanja velikih pomeranja po konturi iskopa, provaljivanja krovine ili zaglavljivanja, odnosno oštećenja tunelske mašine pre postavljanja finalne podgrade. Proces podgrađivanja stenske mase obično započinje ugradnjom ankera odgovarajućih svojstava, i u tačno određenom rasporedu, sa ciljem poboljšanja mehaničkih svojstava stenske mase. $\mathrm{S}$ obzirom na to da se izvođenju finalne podgrade pristupa tek nakon određenog vremena od iskopa, kao i na određenoj udaljenosti od čela (koristeći longitudinalni efekat luka), najpre se postavlja tanak sloj prskanog betona (torkreta) po konturi iskopa, sa ciljem redukovanja pomeranja stenske mase i broja deformisanih ankera (pod pretpostavkom elastičnog-idealno plastičnog ponašanja stenske mase) [1]. Svojstva takvog betona se određuju prema zahtevima projekta i lokalnim geološkim uslovima, pri čemu je neophodno imati u vidu i vremenski promenljivo ponašanje betona. Naime, ukoliko se obloga tunela,

\footnotetext{
* Departman za geologiju, Univerzitet u Beogradu Rudarsko-geološki fakultet, Đušina 7, 11000 Beograd,srdjan.kostic@rgf.bg.ac.rs

** Departman za arhitektonske tehnologije, Univerzitet u Beogradu Arhitektonski fakultet, Beograd

*** Izvedeno istraživanje je podržano od strane Ministarstva prosvete, nauke i tehnološkog razvoja Republike Srbije (Projekat br. 176016).
} 
sastavljena od ankera i prskanog betona sa čeličnim rešetkastim nosačima, postavlja neposredno iza čela iskopa, ankeri i rešetkasti nosači će "odgovoriti” na deformaciju stenske mase po konturi iskopa istovremeno sa daljim napredovanjem tunela. Međutim, $\mathrm{u}$ ovom stadijumu, starost prskanog betona je vrlo mala, i beton nije uspeo da razvije svoju punu nosivost, tako da trenutno opterećenje od stenske mase u ovoj fazi iskopa može da dovede do njegovog loma. Shodno tome, neophodno je pristupiti zaštiti betona od nepovoljnih spoljašnjih uslova, poput iznenadnog zamrzavanja i otkravljivanja, kako bi dostigao očekivanu vrednost pritisne čvrstoće u tako kratkom vremen-skom intervalu. Neophodno je naglasiti da, u ovom slučaju, izvođaču radova nije potrebna smeša betona koja daje očvrsli beton otporan na zamrzavanje/otkravljivanje, već sveža smeša betona koja je otporna na moguće zamrzavanje [2-3]. Prema Uputstvu Američkog Instituta za beton [4], potrebno je pristupiti zaštiti betona od zamrzavanja sve dok ne dostigne čvrstoću na pritisak od 3,5 MPa [5], što obično iznosi 24 h za smešu betona sa vodocementnim (VC) faktorom ispod 0,6 , kada je beton izložen temperaturi $\mathrm{t}=20^{\circ} \mathrm{C}$. Ukoliko se beton izloži zamrzavanju pre nego što dostigne čvrstoću od $3,5 \mathrm{M} \mathrm{Pa}$, njegova konačna čvrstoća na pritisak biće značajno umanjena [6]. Shodno tome, od posebnog je interesa proučavanje otpornosti na mraz svežeg betona za vreme zimskih meseci, sa prosečnom dnevnom temperaturom ispod $0^{\circ} \mathrm{C}$ i do 15 dana uzastopno, i sa minimalnim dnevnim temperaturama ispod $10^{\circ} \mathrm{C}$ [7]. U takvim uslovima, zamrzavanje vode u svežem betonu može dovesti do trajnog oštećenja strukture novoformiranog cementnog matriksa.

I pored velikog broja prethodnih istraživanja o uticaju niskih temperatura na pritisnu čvrstoću betona [8-11], do sada nisu vršena istraživanja uticaja „oštrog", mraza na svojstva svežeg betona, sa temperaturama i do $-25^{\circ} \mathrm{C}$, uključujući i efekat brzih temperaturnih promena, sa amplitudom i do $45^{\circ} \mathrm{C}$ za samo nekoliko dana. Uzimajući u obzir niske temperature zabeležene na području Beograda sa čestim slučajevima oštrog mraza, postoji realna potreba za jednom funkcionalnom antifriz smešom svežeg betona. Ovakvi oštri klimatski uslovi mogli su se očekivati i pri mašinskom iskopu hidrotehničkog tunela u Višnjici, što je moglo dovesti i do zaglavljivanja tunelske mašine.

Osnovni cilj istraživanja je razvoj pouzdanog aditiva, koji bi omogućio izvođenje tunelske obloge bez zaštite od mraza čak i u takvim surovim klimatskim uslovima. Shodno tome, u radu se analizira uticaj različite količine predloženog hemijskog aditiva (4\% i 8\%) na pritisnu čvrstoću svežeg betona pri različitim režimima mraza: jednodnevni mraz $\left(-10^{\circ} \mathrm{C}\right)$, trodnevni mraz $\left(-10^{\circ} \mathrm{C},-5^{\circ} \mathrm{C}\right.$ i $\left.-15^{\circ} \mathrm{C}\right)$, i sedmodnevni mraz (sa oscilacijama temperature između $0^{\circ} \mathrm{C} \mathrm{i}-25^{\circ} \mathrm{C}$ ).

\section{TRAJANJE MRAZA U REALNIM USLOVIMA}

U cilju potvrde realne potrebe za praktičnom primenom antifriz aditiva za prskani beton, najpre je izvršena analiza klimatskih karakteristika na području Beograda u periodu 1993-2012. g. na osnovu podataka Republičkog Hidrometeorološkog zavoda [7]. Analiza ekstremnih slučajeva iznenadnog otopljavanja za decembar, januar, februar i mart izvedena je sa ciljem definisanja prvog i drugog režima mraza. Na slici 1 prikazana je maksimalna zabeležena temperaturna amplituda samo za one dane sa 
prelazom iz negativnih $\mathrm{u}$ pozitivne temperature za dva uzastopna dana (maksi malna vrednost od $16,8^{\circ} \mathrm{C}$ zabeležena je tokom februara 1996.g.).
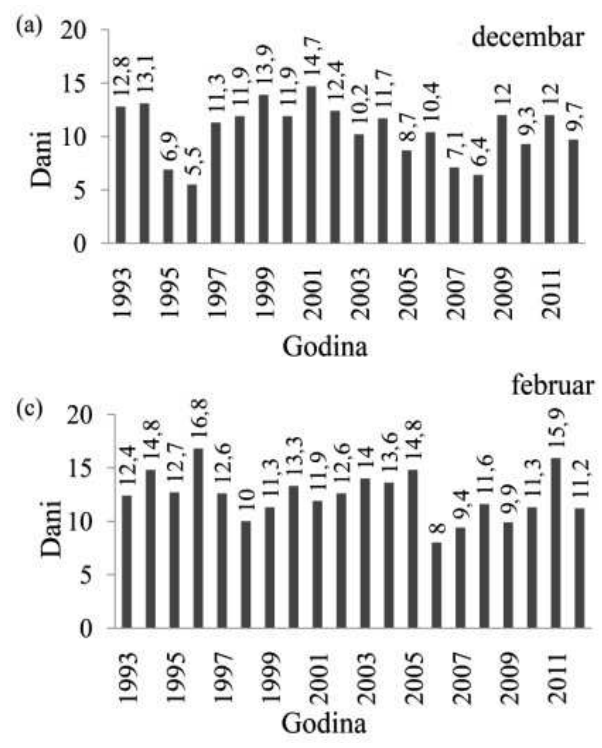
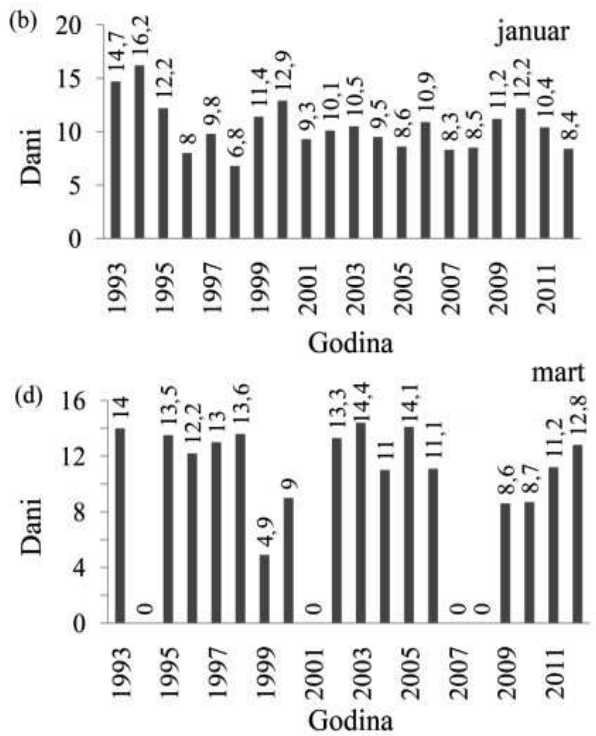

SI. 1. Maksimalne dnevne temperaturne amplitude sa iznenadnim prelazom od negativnih ka pozitivnim vrednostima za dva uzastopna dana u periodu 1993-2012.g. za: (a) decembar, (b) januar, (c) februar; (d) mart. Nulta vrednost se dodeljuje za mesece/godine u kojima nije zabeležen prelaz od negativnih ka pozitivnim temperaturama za dva uzastopna dana

Treći režim mraza, kojem su izloženi uzorci betona, definisan je na osnovu maksimalnog broja uzastopnih dana sa mrazom za decembar, januar, februar i mart, prikazanih na slici 2 (14 dana tokom januara 2009. g. i februara 2012. g.).

\section{EKSPERIMENTALNA PROCEDURA}

U prvoj fazi istraživanja, pritisna čvrstoća betona određivana je na uzorcima sa $\mathrm{i}$ bez hemijskog aditiva nakon nege $u$ vodi $\mathrm{u}$ izotermalnim uslovima $\left(20^{\circ} \mathrm{C}\right)$. U drugoj fazi istraživanja, pristupa se analizi efekta
4\% i 8\% hemijskog aditiva na pritisnu čvrstoću uzoraka betona, nakon njihovog izlaganja različitim režimima mraza. Pri tome, osnovni sastavni elementi betona su (Tabela 1): cement (CEM I 42,5 R, Lafarge Cement, Beočin), agregat (drobljeni kamen, kamenolom Šumnik) i aditiv ("T$\left.25^{\circ} \mathrm{C} "\right)$. Uzorci betona oblika kocke $(10 \times 10 \mathrm{~cm})$ pravljeni su u laboratorijskoj mešalici, sa periodom mešanja od 3 minuta za sve smeše. Livenje je obavljeno na vibracionom stolu dok nije postignuta potpuna konsolidacija. 

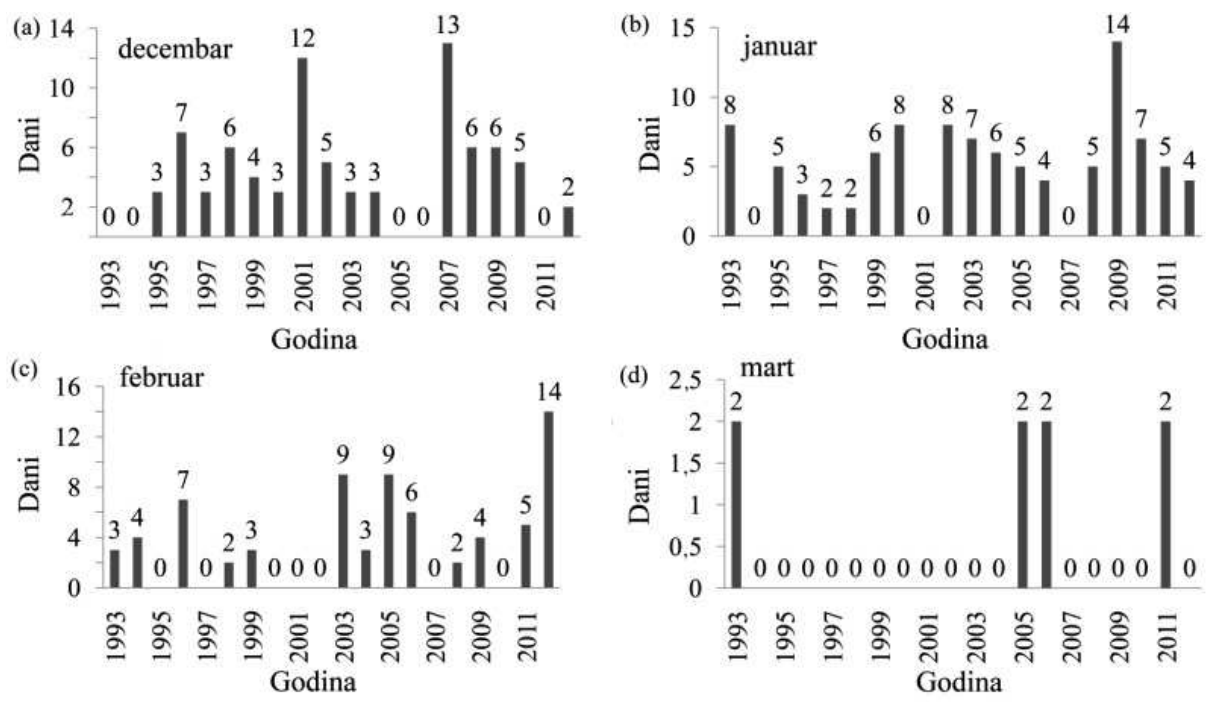

SI. 2. Broj uzastopnih dana sa temperaturom ispod $0^{\circ} \mathrm{C}$ u periodu 1993-2012.g. za: (a) decembar, (b) januar, (c) februar; (d) mart (samo dva i više dana je uzimano u obzir)

Tabela 1. Sastav smeša betona

\begin{tabular}{|l|c|c|c|}
\hline \multicolumn{1}{|c|}{ komponenta po $1 \mathrm{~m}^{3}$ betona } & aditiv 0\% & aditiv $4 \%$ & aditiv $8 \%$ \\
\hline cement: CEM I 42,5 R & $417 \mathrm{~kg}$ & $411 \mathrm{~kg}$ & $408 \mathrm{~kg}$ \\
\hline agregat andezita 0 - 2 mm (30\%) & $574 \mathrm{~kg}$ & $567 \mathrm{~kg}$ & $563 \mathrm{~kg}$ \\
\hline agregat andezita 2 - 4 mm (10\%) & $192 \mathrm{~kg}$ & $189 \mathrm{~kg}$ & $188 \mathrm{~kg}$ \\
\hline agregat andezita 4 - 8 mm (10\%) & $192 \mathrm{~kg}$ & $189 \mathrm{~kg}$ & $188 \mathrm{~kg}$ \\
\hline agregat andezita 8 -11 mm (20\%) & $383 \mathrm{~kg}$ & $378 \mathrm{~kg}$ & $375 \mathrm{~kg}$ \\
\hline agregat andezita $11-16 \mathrm{~mm}(30 \%)$ & $575 \mathrm{~kg}$ & $568 \mathrm{~kg}$ & $563 \mathrm{~kg}$ \\
\hline aditiv & - & $16,4 \mathrm{~kg}$ & $32,6 \mathrm{~kg}$ \\
\hline voda & $167 \mathrm{~kg}$ & $148 \mathrm{~kg}$ & $139 \mathrm{~kg}$ \\
\hline V/C & 0,40 & 0,36 & 0,34 \\
\hline zapreminska težina & $2500 \mathrm{~kg} / \mathrm{m}^{3}$ & $2467 \mathrm{~kg} / \mathrm{m}^{3}$ & $2456 \mathrm{~kg} / \mathrm{m}^{3}$ \\
\hline
\end{tabular}

Uzorci betona za prvu fazu testiranja (u izotermalnim uslovima nege) pripremljeni su prema prethodno opisanoj proceduri, i izliveni u čelične kalupe. Nakon 24 h, referentni uzorci su izvađeni iz kalupa i negovani pod istim uslovima $\mathrm{u}$ vodi na temperaturi od $20^{\circ} \mathrm{C}$. Čvrstoća na pritisak je određena nakon 3,7 i 28 dana. U drugoj fazi istraživanja uzorci su pripremljeni na siti način kao zaprethodnu fazu. Temperatura smeša za vreme livenja iznosila je $20^{\circ} \mathrm{C}$. Odmah nakon livenja, metalni kalupi sa svežim betonom stavljeni su u aklimatizacionu komoru na temperature $-10^{\circ} \mathrm{C}$, a potom su izlagani promeni temperature definisanoj sa tri različita režima mraza: (a) režim mraza 1 simulira jednodnevni mraz, pri čemu su uzorci betona izloženi tempera- 


\section{EKSPERIMENTALNI REZULTATI}

turi od $-10^{\circ} \mathrm{C}$ u toku jednog dana, a potom, drugog dana, uzorci su izloženi temepraturi od $20^{\circ} \mathrm{C}$; (b) režim mraza 2 simlira višednevni mraz, pri čemu se uzorci betona izlažu temperaturi od $-10^{\circ} \mathrm{C}$ tokom prvog dana, a potom blagom porastu temperature do $-5^{\circ} \mathrm{C}$ tokom drugog dana, potom temperaturi od $-15^{\circ} \mathrm{C}$ tokom trećeg dana, a tokom četvrtog dana uzorci se neguju u vodi na temperaturi od $20^{\circ} \mathrm{C}$; (c) režim mraza 3 simulira duži sedmodnevni mraz sa temperaturom prvog dana od $-10^{\circ} \mathrm{C}$, drugog dana od $-5^{\circ} \mathrm{C}$, trećeg dana od $-15^{\circ} \mathrm{C}$, četvrtog dana od $-25^{\circ} \mathrm{C}$, petog dana od $-10^{\circ} \mathrm{C}$ i šestog dana od $-5^{\circ} \mathrm{C}$. U periodu od 8 . do 28 . dana uzorci betona se neguju $\mathrm{u}$ vodi na temperaturi od $20^{\circ} \mathrm{C}$.
Rezultati prve faze istraživanja prikazani su u Tabeli 2. Jasno je da je pritisna čvrstoća betona sa aditivom nakon 3 dana veća od čvrstoće uzoraka bez aditiva. Međutim, nakon sedam dana, nešto veća pritisna čvrstoća zabeležena je za uzorak betona sa $4 \%$ aditiva, dok je značajno manja čvrstoća zabeležena za uzorak sa $8 \%$ aditiva. Sa druge strane, nakon 28 dana čvrstoća na pritisak za uzorak betona sa $4 \%$ aditiva se povećava, a sa $8 \%$ aditiva se nešto smanjuje, ali je i dalje veća $u$ poređenju sa čvrstoćom uzoraka bez aditiva. Izvedeno istraživanje je pokazalo da aditiv ne utiče nepovoljno na očvšćavanje betona nakon 28 dana.

Tabela 2. Svojstva uzoraka betona sa različitom količinom hemijskog aditiva, negovanih u vodi na temperaturi od $20^{\circ} \mathrm{C}$. ${ }^{*}$

\begin{tabular}{|c|c|c|c|c|c|c|c|}
\hline \multirow{2}{*}{$\begin{array}{c}\text { uzorak } \\
\text { broj }\end{array}$} & \multirow{2}{*}{$\begin{array}{l}\text { starost } \\
\text { (dani) }\end{array}$} & \multicolumn{2}{|c|}{$0 \%$ aditiva } & \multicolumn{2}{|c|}{$4 \%$ aditiva } & \multicolumn{2}{|c|}{$8 \%$ aditiva } \\
\hline & & $\begin{array}{c}\gamma \\
\left(\mathrm{kg} / \mathrm{m}^{3}\right) \\
\end{array}$ & $\begin{array}{c}\sigma_{\mathrm{c}} \\
(\mathrm{MPa})\end{array}$ & $\begin{array}{c}\gamma \\
\left(\mathrm{kg} / \mathrm{m}^{3}\right)\end{array}$ & $\begin{array}{c}\sigma_{\mathrm{c}} \\
(\mathrm{MPa})\end{array}$ & $\begin{array}{c}\gamma \\
\left(\mathrm{kg} / \mathrm{m}^{3}\right)\end{array}$ & $\begin{array}{c}\sigma_{\mathrm{c}} \\
(\mathrm{MPa})\end{array}$ \\
\hline 1 & \multirow{3}{*}{3} & 2470 & 52,0 & 2405 & 57,5 & 2490 & 61,0 \\
\hline 2 & & 2460 & 52,0 & 2420 & 58,0 & 2480 & 62,0 \\
\hline 3 & & 2460 & 51,0 & 2490 & 54,5 & 2480 & 65,0 \\
\hline 4 & \multirow{3}{*}{7} & 2470 & 77,4 & 2470 & 74,5 & 2420 & 66,2 \\
\hline 5 & & 2580 & 73,8 & 2450 & 78,0 & 2460 & 64,0 \\
\hline 6 & & 2450 & 72,0 & 2450 & 72,0 & 2440 & 68,5 \\
\hline 7 & \multirow{3}{*}{28} & 2460 & 88,5 & 2450 & 93,0 & 2470 & 83,7 \\
\hline 8 & & 2470 & 70,6 & 2470 & 84,0 & 2470 & 96,5 \\
\hline 9 & & 2440 & 81,0 & 2450 & 90,0 & 2430 & 81,6 \\
\hline
\end{tabular}

* y označava zapreminsku težinu, a $\sigma_{c}$ je čvrstoća na pritisak uzorka betona.

U drugoj fazi istraživanja, pritisna čvrstoća betona određena je nakon izlaganja uzoraka različitim režimima mraza, sa temperaturom do $-25^{\circ} \mathrm{C}$. Postupak ispitivanja se sastojao u sledećem. Najpre je ispitan efekat zamrzavanja na uzorke svežeg betona bez hemijskog aditiva (Tabela 3). 
Tabela 3. Zapreminska težina i čvrstoća na pritisak uzoraka betona bez hemijskog aditiva

\begin{tabular}{|c|c|c|c|c|c|c|c|c|}
\hline \multirow{2}{*}{$\begin{array}{c}\text { uzorak } \\
\text { broj }\end{array}$} & \multirow{2}{*}{$\begin{array}{l}\text { režim } \\
\text { mraza }\end{array}$} & \multicolumn{2}{|c|}{ starost (dani) } & \multirow{2}{*}{$\begin{array}{l}\text { ekvivalentna } \\
\text { starost }\left(\mathrm{t}_{\mathrm{e}}\right)^{*}\end{array}$} & \multicolumn{4}{|c|}{ svojstva betona bez aditiva } \\
\hline & & $<0^{\circ} \mathrm{C}$ & $=20^{\circ} \mathrm{C}$ & & $\gamma\left(\mathrm{kg} / \mathrm{m}^{3}\right)$ & $\begin{array}{c}\text { srednja } \\
\text { vrednost }\end{array}$ & $\sigma_{\mathrm{c}}(\mathrm{MPa})$ & $\begin{array}{l}\text { srednja } \\
\text { vrednost }\end{array}$ \\
\hline 1 & 1 & 1 & 1 & 1 & 2455 & \multirow{2}{*}{2478} & 7,9 & \multirow{2}{*}{8,2} \\
\hline 2 & 1 & 1 & 1 & 1 & 2500 & & 8,5 & \\
\hline 3 & 2 & 3 & 1 & 1 & 2430 & \multirow{2}{*}{2420} & 10,1 & \multirow{2}{*}{10,2} \\
\hline 4 & 2 & 3 & 1 & 1 & 2410 & & 10,4 & \\
\hline 5 & 3 & 7 & 1 & 0,83 & 2410 & \multirow{3}{*}{2400} & 11,8 & \multirow{3}{*}{12,1} \\
\hline 6 & 3 & 7 & 1 & 0,83 & 2390 & & 12,4 & \\
\hline 7 & 3 & 7 & 1 & 0,83 & 2355 & & 16,7 & \\
\hline 8 & 3 & 7 & 3 & 2,83 & 2530 & \multirow{3}{*}{2425} & 19,0 & \multirow{3}{*}{17,6} \\
\hline 9 & 3 & 7 & 3 & 2,83 & 2390 & & 17,1 & \\
\hline 10 & 3 & 7 & 3 & 2,83 & 2390 & & 21,0 & \\
\hline 11 & 3 & 7 & 7 & 6,83 & 2410 & \multirow{3}{*}{2397} & 21,8 & \multirow{3}{*}{21,5} \\
\hline 12 & 3 & 7 & 7 & 6,83 & 2390 & & 21,8 & \\
\hline 13 & 3 & 7 & 7 & 6,83 & 2525 & & 31,0 & \\
\hline 14 & 3 & 7 & 28 & 27,83 & 2410 & \multirow{2}{*}{2440} & 28,0 & \multirow{2}{*}{29,3} \\
\hline 15 & 3 & 7 & 28 & 27,83 & 2385 & & 29,0 & \\
\hline
\end{tabular}

*ekvivalentno vreme ( $t_{e}$ ) određeno je na osnovu Solovog modela [12]

Rezultati eksperimentalne analize pri- je mnogo veća, skoro i do tri puta (za režim tisne čvrstoće uzoraka betona sa 4\% i $8 \%$ mraza 1 od 8,2 $\mathrm{MPa}$ do 25,9 $\mathrm{MPa}$ sa 4\% aditiva prikazani su u Tabelama 4 i 5 . U oba aditiva) u poređenju sa pritisnom čvrstoćom slučaja, čvrstoća na pritisak uzoraka betona na uzorcima betona bez aditiva (Tabela 3 ).

Tabela 4. Svojstva uzoraka betona sa 4\% hemijskog aditiva

\begin{tabular}{|c|c|c|c|c|c|c|c|c|}
\hline \multirow[b]{2}{*}{$\begin{array}{c}\text { uzorak } \\
\text { broj }\end{array}$} & \multirow[b]{2}{*}{$\begin{array}{l}\text { režim } \\
\text { mraza }\end{array}$} & \multicolumn{2}{|c|}{ starost (dani) } & \multirow[b]{2}{*}{$\begin{array}{l}\text { ekvivalentna } \\
\text { starost }\left(\mathrm{t}_{\mathrm{e}}\right)\end{array}$} & \multicolumn{4}{|c|}{ svojstva betona sa $4 \%$ aditiva } \\
\hline & & $<0^{\circ} \mathrm{C}$ & $=20^{\circ} \mathrm{C}$ & & $\begin{array}{c}\gamma \\
\left(\mathrm{kg} / \mathrm{m}^{3}\right)\end{array}$ & $\begin{array}{c}\text { srednja } \\
\text { vrednost }\end{array}$ & $\sigma_{\mathrm{c}}(\mathrm{MPa})$ & $\begin{array}{c}\text { srednja } \\
\text { vrednost }\end{array}$ \\
\hline 1 & 1 & 1 & 1 & 1 & 2440 & \multirow{2}{*}{2445} & 25,8 & \multirow{2}{*}{25,9} \\
\hline 2 & 1 & 1 & 1 & 1 & 2450 & & 26,0 & \\
\hline 3 & 2 & 3 & 1 & 1 & 2470 & \multirow{2}{*}{2460} & 15,2 & \multirow{2}{*}{15,6} \\
\hline 4 & 2 & 3 & 1 & 1 & 2450 & & 16,1 & \\
\hline 5 & 3 & 7 & 1 & 0,83 & 2440 & \multirow{3}{*}{2445} & 26,0 & \multirow{3}{*}{25,2} \\
\hline 6 & 3 & 7 & 1 & 0,83 & 2450 & & 24,3 & \\
\hline 7 & 3 & 7 & 1 & 0,83 & 2380 & & 31,0 & \\
\hline 8 & 3 & 7 & 3 & 2,83 & 2380 & \multirow{3}{*}{2390} & 31,5 & \multirow{3}{*}{31,5} \\
\hline 9 & 3 & 7 & 3 & 2,83 & 2410 & & 32,0 & \\
\hline 10 & 3 & 7 & 3 & 2,83 & 2370 & & 45,0 & \\
\hline 11 & 3 & 7 & 7 & 6,83 & 2410 & \multirow{3}{*}{2390} & 39,5 & \multirow{3}{*}{43,1} \\
\hline 12 & 3 & 7 & 7 & 6,83 & 2390 & & 44,8 & \\
\hline 13 & 3 & 7 & 7 & 6,83 & 2440 & & 50,7 & \\
\hline 14 & 3 & 7 & 28 & 27,83 & 2460 & \multirow{2}{*}{2453} & 53,8 & \multirow{2}{*}{53,6} \\
\hline 15 & 3 & 7 & 28 & 27,83 & 2460 & & 56,4 & \\
\hline
\end{tabular}


Neophodno je naglasiti da je razlika u ponašanju uzoraka betona sa $4 \%$ i $8 \%$ aditiva vrlo mala, što ukazujena činjenicu da dalje dodavanje hemijskog aditiva ne bi doprinelo značajnijem povećanju čvrstoće na pritisak uzoraka betona. $\mathrm{S}$ druge strane, iako se zapaža značajno povećanje pritisne čvrstoće u poređenju sa uzorcima bez aditiva (Tabele 3, 4 i 5), registrovane vrednosti su i dalje niže u odnosu na pritisnu čvrstoću uzoraka betona negovanih u izotermalnim uslovima (Tabela 2).

Tabela 5. Zapreminska težina i čvrstoća na pritisak uzoraka betona sa $8 \%$ hemijskog aditiva

\begin{tabular}{|c|c|c|c|c|c|c|c|c|}
\hline \multirow[b]{2}{*}{$\begin{array}{c}\text { uzorak } \\
\text { broj }\end{array}$} & \multirow[b]{2}{*}{$\begin{array}{l}\text { režim } \\
\text { mraza }\end{array}$} & \multicolumn{2}{|c|}{ starost (dani) } & \multirow[b]{2}{*}{$\begin{array}{l}\text { ekvivalentna } \\
\text { starost }\left(\mathrm{t}_{\mathrm{e}}\right)\end{array}$} & \multicolumn{4}{|c|}{ svojstva betona sa $8 \%$ aditiva } \\
\hline & & $<0^{\circ} \mathrm{C}$ & $=20^{\circ} \mathrm{C}$ & & $\gamma\left(\mathrm{kg} / \mathrm{m}^{3}\right)$ & $\begin{array}{c}\text { srednja } \\
\text { vrednost }\end{array}$ & $\sigma_{\mathrm{c}}(\mathrm{MPa})$ & $\begin{array}{c}\text { srednja } \\
\text { vrednost }\end{array}$ \\
\hline 1 & 1 & 1 & 1 & 1 & 2440 & \multirow{2}{*}{2440} & 17,0 & \multirow{2}{*}{17,6} \\
\hline 2 & 1 & 1 & 1 & 1 & 2440 & & 18,1 & \\
\hline 3 & 2 & 3 & 1 & 1 & 2430 & \multirow{2}{*}{2445} & 24,0 & \multirow{2}{*}{23,8} \\
\hline 4 & 2 & 3 & 1 & 1 & 2460 & & 23,7 & \\
\hline 5 & 3 & 7 & 1 & 0,83 & 2430 & \multirow{3}{*}{2435} & 38,7 & \multirow{3}{*}{39,4} \\
\hline 6 & 3 & 7 & 1 & 0,83 & 2440 & & 40,2 & \\
\hline 7 & 3 & 7 & 1 & 0,83 & 2410 & & 41,0 & \\
\hline 8 & 3 & 7 & 3 & 2,83 & 2385 & \multirow{3}{*}{2402} & 40,0 & \multirow{3}{*}{40,5} \\
\hline 9 & 3 & 7 & 3 & 2,83 & 2410 & & 40,5 & \\
\hline 10 & 3 & 7 & 3 & 2,83 & 2410 & & 46,3 & \\
\hline 11 & 3 & 7 & 7 & 6,83 & 2420 & \multirow{3}{*}{2403} & 46,5 & \multirow{3}{*}{47,9} \\
\hline 12 & 3 & 7 & 7 & 6,83 & 2380 & & 51,0 & \\
\hline 13 & 3 & 7 & 7 & 6,83 & 2430 & & 56,1 & \\
\hline 14 & 3 & 7 & 28 & 27,83 & 2450 & \multirow{2}{*}{2443} & 69,4 & \multirow{2}{*}{61,0} \\
\hline 15 & 7 & 7 & 28 & 27,83 & 2450 & & 57,4 & \\
\hline
\end{tabular}

U cilju poređenja čvrstoće na pritisak uzoraka betona nakon izlaganja različitim režimima mraza (sa i bez aditiva) i pritisne čvrstoće uzoraka negovanih u izotermalnim uslovima, procena pritisne čvrstoće uzoraka betona izvedena je za sledeće dane: 0,$83 ; 1 ; 2,83 ; 6,83$ i 27,83 , što predstavlja ekvivalentnu starost za sve ispitivane slučajeve (četvrta kolona u tabelama 3, 4 i 5). Čvrstoća na pritisak uzoraka betona za navedene dana ocenjena je koristeći Ploumanov model (Slika 3), koji daje vezu između čvrstoće betona negovanog u izotermalnim uslovima i zrelosti betona po Solu:

$$
S_{p}=a+b \times \log M_{s}
$$

gde je:

- $S_{p}$ - predviđena vrednost čvrstoće na osnovu Ploumanove jednačine [13],
- $M_{s}$ - je zrelost betona na osnovu Solovog modela [12], a

- $a$ i $b$ su konsatnte.

Zrelost betona $M_{s}$ određena je na osnovu ekvivalentne starosti, uzimajući $\mathrm{u}$ obzir spregnuti uticaj proteklog vremena i temperature na razvoj čvrstoće [14]:

$$
t_{e}=\left(\sum_{1}^{n}\left(T-T_{0}\right) \times \Delta t_{i}\right) /\left(T_{r}-T_{0}\right),
$$

gde je:

- $t_{e}$ - ekvivalentna starost,

- $T$ - je temperatura očvršćavanja betona u vremenskom intervalu $\Delta t_{i}$,

- $T_{0}$ - označava referentnu temperaturu $\left(-10^{\circ} \mathrm{C}\right)$,

- $T_{r}$ - je temperatura nege betona $\left(20^{\circ} \mathrm{C}\right)$, a

- $\Delta t_{i}$ - je posmatrani vremenski interval. 
Očigledno je, na osnovu slike 3 , da Ploumanov model daje zadovoljavajuću procenu eksperimentalnih rezultata, sa visokim koeficijentom korelacije $(r>0,8)$ i niskom vrednošću srednje kvadratne greške
(RMSE $\leq 7,14)$. Prema tome, vrednosti čvrstoće na pritisak za ekvivalentnu starost mogu da se očitaju sa ovih dijagrama sa zadovoljavajućom tačnošću (četvrta kolona u tabelama 3,4 i 5).
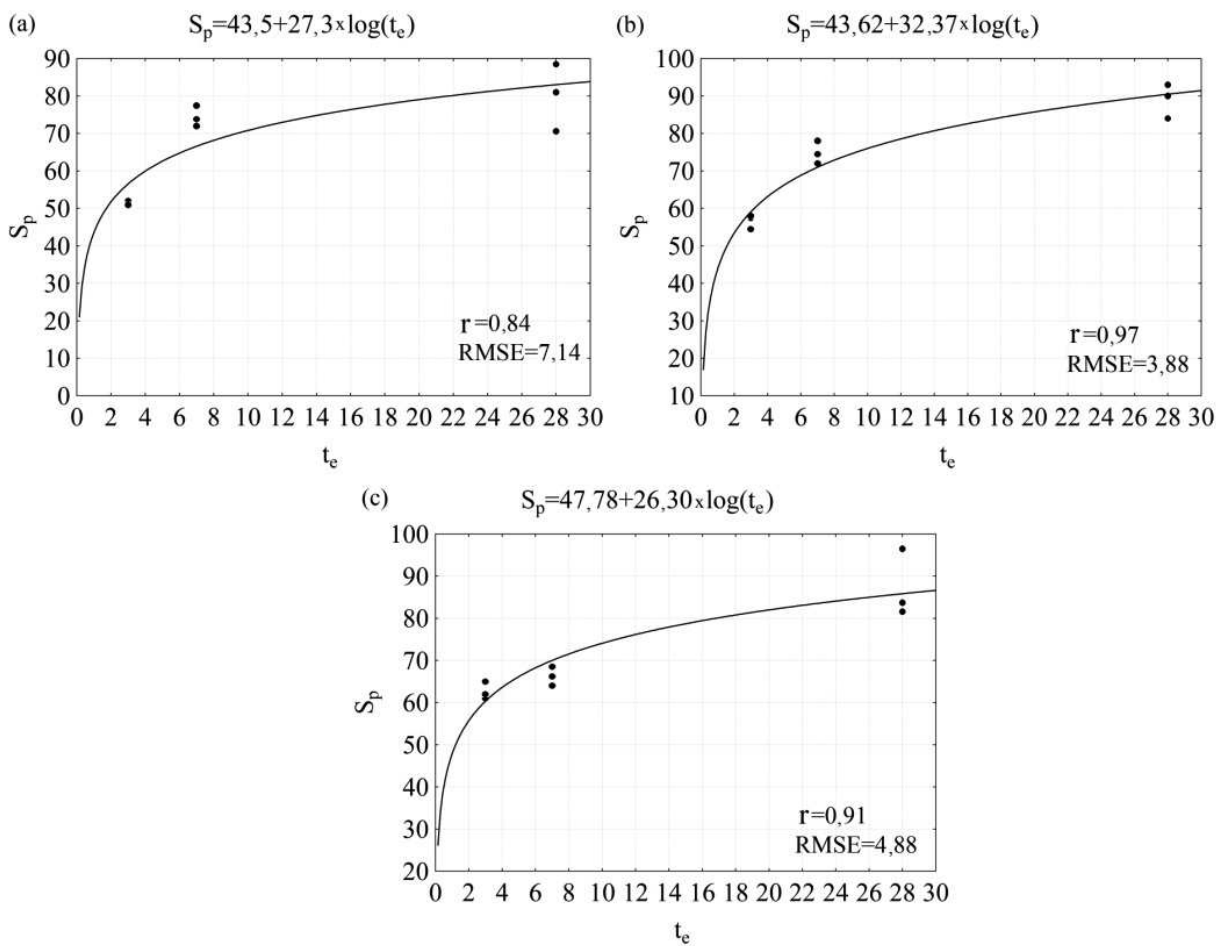

Sl. 3. Rezultati predviđanja čvrstoće na pritisak uzoraka betona pomoću Ploumanovog modela sa različitom količinom aditiva, negovanih u izotermalnim uslovima (u vodi na temperaturi $20^{\circ} \mathrm{C}$ ): (a) $0 \%$ aditiva; (b) $4 \%$ aditiva; (c) $8 \%$ aditiva

Poređenje čvrstoće na pritisak betona negovanog u izotermalnim uslovima i nakon izlaganja različitim režimima mraza prikazano je u Tabeli 6. Jasno je da uzorci betona sa $8 \%$ aditiva postižu $86,3 \%$ željene pritisne čvrstoće, za režim mraza 3 sa sedmodnevnim mrazom i samo jednim danom otkravljivanja.
Isti uzorci postižu $71,1 \%$ željene pritisne čvrstoće za režim mraza 3 sa sedmodnevnim mrazom i 21 danom otkravljivanja. U svim drugim slučajevima, uzorci betona postižu manje od $70 \%$ pritisne čvrstoće referentnih uzoraka negovanih pod izotermalnim uslovima $\mathrm{u}$ vodi na temperaturi od $20^{\circ} \mathrm{C}$. 
Tabela 6. Smanjenje čvrstoće na pritisak uzoraka betona sa i bez hemijskog aditiva, negovanih u izotermalnim uslovima, i pri delovanju različitih temperaturnih režima

\begin{tabular}{|c|c|c|c|c|c|c|c|c|c|}
\hline \multirow[b]{2}{*}{ 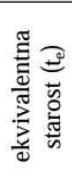 } & \multicolumn{3}{|c|}{$\sigma_{\mathrm{c}}(\mathrm{MPa})$ sa $0 \%$ aditiva } & \multicolumn{3}{|c|}{$\sigma_{\mathrm{c}}(\mathrm{MPa})$ sa $4 \%$ aditiva } & \multicolumn{3}{|c|}{$\sigma_{\mathrm{c}}(\mathrm{MPa})$ sa $8 \%$ aditiva } \\
\hline & 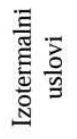 & 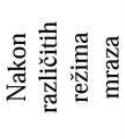 & 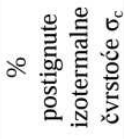 & 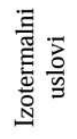 & 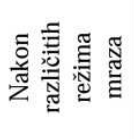 & 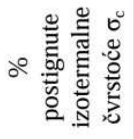 & 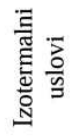 & 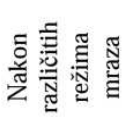 & 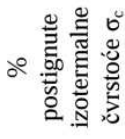 \\
\hline 0,83 & 41,29 & 12,1 & 29,3 & 41,00 & 25,2 & 61,5 & 45,65 & 39,4 & 86,3 \\
\hline 1 & 43,50 & $8,2-10,2$ & $18,9-23,5$ & 43,62 & $15,6-25,9$ & $35,8-59,4$ & 47,78 & $17,6-23,8$ & $36,8-49,8$ \\
\hline 2,83 & 55,83 & 17,6 & 31,5 & 58,24 & 31,5 & 54,1 & 59,66 & 40,5 & 67,9 \\
\hline 6,83 & 66,28 & 21,5 & 32,4 & 70,63 & 43,1 & 61,0 & 69,73 & 47,9 & 68,7 \\
\hline 27,83 & 82,94 & 29,3 & 35,3 & 90,38 & 53,6 & 59,3 & 85,77 & 61,0 & 71,1 \\
\hline
\end{tabular}

\section{ZAKLJUČAK}

U radu se analizira efekat hemijskog aditiva na čvrstoću na pritisak uzoraka betona nakon izlaganja različitim režimima mraza. U sva tri ispitana slučaja, uzorci betona sa hemijskim aditivom dostigli su znatno višu pritisnu čvrstoću (čak i do $200 \%$ veću) u odnosu na uzorke bez hemijskog aditiva. Rezultati analize potvrđuju da se primenom hemijskog aditiva može sprečiti lom svežeg prskanog betona čak i takvim oštrim zimskim uslovima.

Naglasimo da je poređenje pritisnih čvrstoća zabeleženih pri različitim temperaturnim uslovima (Tabela 6) izvedeno korišćenjem regresione analize (Ploumanov model), što može dovesti do nepouzdanih interpretacija. Međutim, relativno visoka vrednost koeficijenta korelacije $(r>0.8)$ ukazuje na to da je moguća greška u proceni pritisne čvrstoće $u$ intervalu greške merenja. S druge strane, izvedena analiza je u znatnoj meri ograničena malim brojem ispitanih uzoraka betona: u pojedinim slučajevima ispitivana su po tri uzorka, što je i uobičajeno u laboratorijskoj praksi, dok su, u drugim slučajevima, svojstva betona određivana na samo dva uzorka. Međutim, čak i sa većim brojem uzoraka, ne bi trebalo očekivati značajnije promene u pogledu dostignute pritisne čvrstoće sa dodatim hemijskim aditivom.
U pogledu pravca daljih istraživanja, izvedena analiza bi trebalo biti proširena dodatnim analizama efekta predloženog hemijskog aditiva, pre svega u odnosu na postizanje željene čvrstoće na pritisak betona. Naravno, buduća istraživanja bi morala uzeti u obzir i ekonomske efekte, sa ciljem određivanja najpovoljnijeg procenta aditiva, koji obezbeđuje najveću pritisnu čvrstoću betona. Ovi opiti bi morali da budu izvedeni u realnim uslovima, in situ, postavljanjem svežeg betona po konturi iskopa, čime bi se obuhvatio i uticaj pomeranja stenske mase ka tunelskom otvoru na razvoj čvrstoće mladog prskanog betona. Na taj način, bila bi izvršena još realnija procena efekta hemijskog aditiva na stabilnost i postojanost svežeg prskanog betona.

\section{LITERATURA}

[1] Hoek, E., Carranza-Torres, C., Diederichs, M. The 2008 Kersten Lecture: Integration of Geotechnical and Structural Design in Tunneling. Proceedings of $56^{\text {th }}$ Annual Geotechnical Engineering Conference, Minneapolis, 2008; 53 p.

[2] Aitcin, P. C. The Durability Characteristics of High Performance Concrete: a Review. Cement Concrete Comp. 2003; 25: p. 409-420. 
[3] Neville, A. M. Properties of Concrete. $5^{\text {th }}$ ed. Edinburgh: Pearson Education Limited; 2012.

[4] ACI 306 Committee. Guide to Cold Weather Concreting, ACI 306R-10. Farmington Hills, Michigan: American Concrete Institute; 2010.

[5] Powers, T. C. Prevention of Frost Damage to Green Concrete. RILEM 1962; 14: p. 120-124.

[6] Kosmatka, S. H., Kerkhoff, B., Panarese, W. C. Design and Control of Concrete Mixtures. $14^{\text {th }}$ ed. Skokie, Illinois: Portland Cement Association; 2003.

[7] Yearbooks of Hydrometeorological Service of Serbia, 1993-2012.

[8] Nmai, C. K. Cold Weather Concreting Admixtures. Cement Concrete Comp. 1998; 20:121-128.

[9] Husem, M., Gozutok, S. The Effects of Low Temperature Curing on the Compressing Strength of Ordinary and High Performance Concrete. Constr. Build. Mater. 2005;19:49-53.
[10] Barna, L. A., Seman, P. M., Korhonen, C. J. Energy-efficient Approach to Cold-Weather Concreting. Journal of Materials in Civil Engineering, Special Issue: Energy Efficient and Environmentally Friendly Paving Materials 2011; 23: 1544-1551.

[11] Cullu, M., Arslan, M. The Effects of Antifreeze Use on Physical and Mechanical Properties of Concrete Produced in Cold Weather. Composites: Part B 2013; 50:p. 202-209.

[12] Saul, A. G. A. Principles Underlying the Steam Curing of Concrete at Atmospheric Pressure. Mag. Concr. Res. 1951; 2: p. 127 - 140.

[13] Plowman, J. M. Maturity and the Strength of Concrete. Mag. Concr. Res. 1956;8: p. 13 - 22.

[14] Yi, S. T., Moon, Y. H., Kim, J. K. Long-term Strength Prediction of Concrete With Curing Temperature. Cement Concrete Res. 2005; 35; p. 1961-1969. 